\title{
PENGARUH FAKTOR EKUITAS MEREK TERHADAP KEPUTUSAN PEMBELIAN SABUN DETERJEN MEREK RINSO DI KELURAHAN LAYANA INDAH KOTA PALU
}

\author{
SURIANI LABOLO \\ MASKURI SUTOMO \\ RAHMAT MUBARAQ \\ Jurusan Manajemen, Fakultas Ekonomi, Universitas Tadulako \\ Suryani.labolo07@yahoo.co.id
}

\begin{abstract}
The research aims to analyze the influence of brand equity that consists of brand awareness, quality perception, brand association, and brand loyalty, on customer purchase decision to buy Rinso at Layana Indah Village in Palu. Sample size of the study is 72 respondents who selected through purposive sampling technique. The results indicate that all variables, namely brand awareness, quality perception, brand association, and brand loyalty simultaneously have significant influence on customer purchase decision. The Adjusted $R$ square of 0.527 indicates that brand equity has 52,7 percent of the variability of customer purchase decision, while 47,3 percent influenced by other variables that are not studied. Partially, all variables have positive and significant influence on customer purchase decision to buy Rinso detergent.
\end{abstract}

Keywords: brand awareness, perceived quality, brand association, brand loyalty, consumer decision.

\begin{abstract}
Abstrak
Tujuan penelitian ini adalah untuk mengetahui pengaruh ekuitas merek yang terdiri atas kesadaran merek, persepsi kualitas, asosiasi merek, dan loyalitas merek terhadap keputusan pembelian produk deterjen merek Rinso di Kelurahan Layana Indah Kota Palu. Sampel dalam penelitian ini sebanyak 72 orang dengan teknik penarikan sampel menggunakan purposive sampling. Hasil penelitian menunjukan bahwa secara simultan variabel ekuitas merek yang terdiri dari kesadaran merek, persepsi kualitas, asosiasi merek dan loyalitas merek memiliki pengaruh signifikan terhadap keputusan konsumen sehingga apabila variabel ekuitas merek diterapkan secara baik maka keputusan pembelian juga akan meningkat, dengan nilai adjusted $\mathrm{R}$ square 0.527 , artinya bahwa ekuitas merek berpengaruh terhadap keputusan pembelian sebesar $52.7 \%$ dan sisanya sebesar $47.3 \%$ dipengaruhi oleh variabel lain yang tidak diteliti. Secara parsial variabel kesadaran merek, persepsi kualitas, asosiasi merek dan loyalitas merek berpengaruh signifikan terhadap keputusan pembelian dalam menggunakan produk sabun deterjen merek Rinso.
\end{abstract}

Kata Kunci: Kesadaran Merek, Persepsi Kualitas, Asosiasi Merek, Loyalitas Merek, Keputusan Konsumen

\section{PENDAHULUAN}

Pemasaran merupakan salah satu kegiatan yang dilakukan dalam menghadapi persaingan dengan mengusahakan agar produk yang dipasarkannya dapat diterima dan disenangi oleh pasar. Dewasa ini banyak perusahaan-perusahaan kecil yang mulai mengembangkan usahanya, begitu pula dengan perusahaan-perusahaan besar yang tetap eksis dan terus memperluas pasarsasarannya. Salah satu perusahaan tersebut adalah PT. Unilever yang salah satu produknya adalah deterjen.

Sabun deterjen sebagai salah satu sarana perawatan pakaian yang sudah dikenal oleh masyarakat Indonesia sejak lama. Produk sabun deterjen masuk dalam daftar belanja tiap rumah tangga. Dengan jumlah penduduk Indonesia yang besar, kebutuhan akan deterjen menjadi potensi bisnis besar. Peluang itu ditangkap para pelaku usaha dan lahirlah beragam merek, bentuk dan ukuran produk sabun deterjen.

Kelurahan Layana Indah terletak di Kecamatan Mantikulore Kota Palu Propinsi Sulawesi Tengah, Indonesia. Arti Layana adalah Air kecil yang tergenang yang tidak mengalir kemana-mana, 
(Kelurahan Layana Indah 2014) disamping itu pula pada tahun 1991 Layana sangat ramai karena adanya transmigrasi sehingga dikatakan indah. Bahasa yang digunakan adalah Torai dan Tara. Layana Indah terletak pada titik koordinat: LS 0048 " 26.6 dan BT 11945 "10.6.

Demi menjaga persaingan dan terus mempertahankan pangsa pasar, setiap produk suatu perusahaan tidak terkecuali produk deterjen merek Rinso harus terus dapat meningkatkan kualitas produk dan ekuitas merek (brand equity) yang tinggi. Sehingga dapat melakukan pengembangan pasar dan mendorong konsumen untuk melakukan identifikasi dalam pengambilan keputusan saat menentukan suatu merek yang menurut mereka memenuhi kriteria sebuah produk deterjen yang ideal.

\section{KAJIAN LITERATURE DAN PENGEMBANGAN HIPOTESIS}

Menurut Kotler dan Keller (2009:5) manajemen pemasaran (marketing management) adalah sebagai seni dan ilmu pemilih pasar sasaran dan meraih, mempertahankan, serta menumbuhkan pelanggan dengan menciptakan, mengantarkan, dan mengkomunikasikan nilai pelanggan yang unggul.

American Marketing Association ( dalam Kotler dan Keller, 2009: 258) mendefinisikan merek (brand) sebagai mana, istilah, tanda, lambang, atau desain, atau kombinasi, yang dimaksudkan untuk mengidentifikasikan barang atau jasa dari salah satu penjual atau kelompok penjual dan untuk mengidentifikasikan merek dari para pesaing. Dengan demikian sebuah merek adalah produk atau jasa yang dimensinya mendiferensikan merek tersebut dengan beberapa cara dari produk atau jasa lainnya yang dirancang untuk memuaskan kebutuhan yang sama. Perbedaan ini bisa fungsional, rasional, atau nyata dengan kinerja produk dari merek.

\section{Tahap Proses Pengambilan Keputusan Pembeli}

Tahapan-tahapan dalam proses pengambilan keputusan pembelian, konsumen harus melewati lima tahapan yaitu, pengenalan masalah, pencarian informasi, evaluasi alternative, keputusan pembelian, dan perilaku pasca pembelian (Kotler dan Keller 2009:184)

Tahapan proses pengambilan keputusan pembeli yang dikemukakan oleh kotler dan kaller diatas dapat dilihat pada gambar berikut ini:

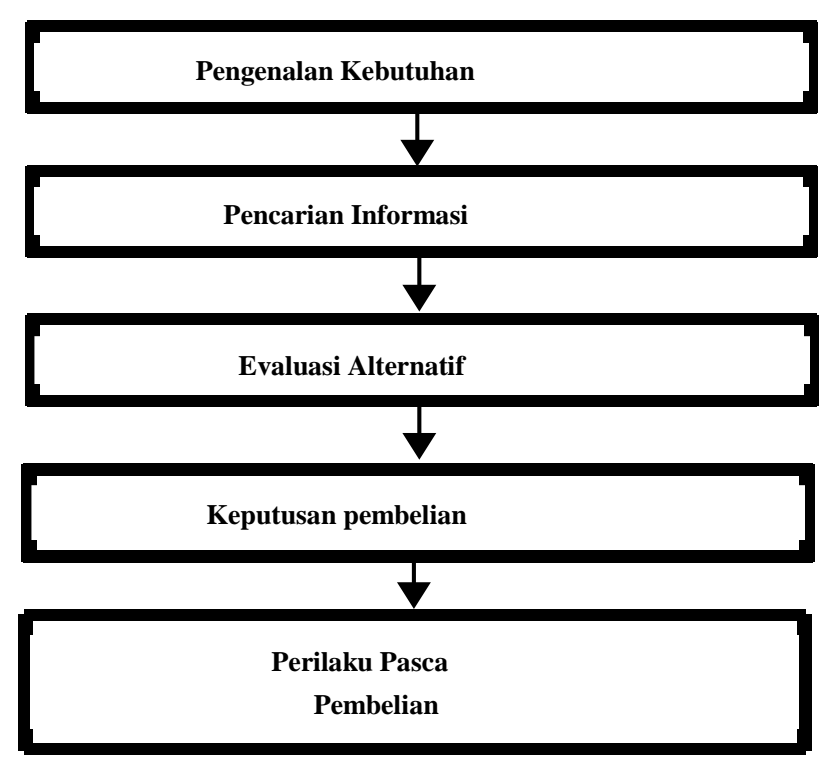

Sumber : Kotler \& Keller (2009)

Gambar 1

Proses Pembelian Konsumen Model Lima Tahap 
Penjelasan gambar 1 sebagai berikut:

1. Pengenalan masalah

Proses pembelian dimulai ketika pembeli menyadari suatu masalah atau kebutuhan yang dipicu oleh rangsangan internal ataueksternal. Dengan ransangan internal, salah satu dari kebutuhan normal seseorang seperti rasa lapar, haus naik ketingkat maksimum dan menjadI dorongan, atau kebutuhan bisa timbul akibat rangsangan eksternal. Pasar harus mengidentifikasi keadaan yang memicu kebutuhan tertentu dengan mengumpulkan informasi dari sejumlah konsumen. Lalu mereka dapat mengembangkan startegi pemasaran yang memicu minat konsumen. Terutama untuk pembelian fleksibel seperti barang-barang mewah, paket liburan, dan pemilihan liburan, pemasar mungkin harus meningkatkan motivasi konsumen sehingga pembelian potensial mendapat pertimbangan serius.

2. Pencarian informasi

Konsumen sering mencari sejumlah informasi yang terbetas. Dimana sumber informasi di antaranya: pribadi, komersial, publik, dan eksperimental. Setiap sumber informasi melaksanakan fungsi yang berbeda dalam mempengaruhi keputusan pembelian.

3. Evaluasi alternatif

Beberapa konsep dasar yang akan membantu kita memahami proses evaluasi: pertama, konsumen berusaha memuaskan sebuah kebutuhan. Kedua, konsumen mencari manfaat tertentu dari solusi produk .Ketiga, konsumen melihat masing-masing produk sebagai sekelompok atribut dengan berbagai kemampuan untuk menghantarkan manfaat yang diperlukan untuk memuaskan kebutuhan.

4. Keputusan pembelian

Konsumen tidak harus menggunakan satu jenis aturan pilihan saja. terkadang, mereka menerapkan strategi keputusan menggabungkan dua pilihan atau lebih. Keputusan konsumen untuk memodifikasi, menunda, atau menghindari keputusan pembelian sangat dipengaruhi oleh anggapan resiko. Konsumen dapat menilai banyak jenis resiko dalam membeli dan mengkonsumsi sebuah produk.

5. Perilaku pasca pembelian

Setelah pembelian, konsumen mungkin akan mengalami konfilk dikarenakan melihat fitur mengkhawatirkan atau mendengarkan hal-hal menyenangkan tentang merek lain dan waspada terhadap informasi yang mendukung keputusannya. Komunikasi pemasaran seharusnya memasok keyakinan dan evaluasi yang memperkuat pilihan konsumen dan membantunya merasa nyaman tentang merek tersebut.

\section{METODE PENELITIAN}

Tipe penelitian yang digunakan dalam penelitian ini bersifat deskriptif kausal dengan alasan peneliti akan menggambarkan secara sistematis sejauh mana hubungan serta pengaruh dari variabel independen dalam hal ini adalah ekuitas merek (breand equity) yang terdiri atas dari: brand awareness (kesadaran merek), perceived quality (kesan kualitas), brand associations ( asosiasi merek ) dan brand loyalty (loyalitas merek) terhadap variabel dependen dalam hal ini yaitu keputusan konsumen dalam membeli sabun deterjen merek Rinso di Kelurahan Layana Indah Kota Palu.

Populasi Menurut Sugiyono (2008:117) adalah wilayah generalisasi yang terdiri atas obyek dan subyek yang mempunyai kualitas dan karakteristik tertentu yang ditetapkan oleh peneliti untuk dipelajari dan kemudian ditarik kesimpulannya. Populasi dalam penelitian ini adalah konsumen sabun deterjen merek Rinso di Kelurahan Layana Indah Kota Palu. 
Jumlah populasi pengguna produk Rinso di Kelurahan Layana Indah jumlahnya tidak diketahui, sehingga berdasarkan teori yang Guy (dalam Umar, 2000: 147) bahwa ukuran sampel yang dapat diterima berdasarkan desain penelitian yang digunakan dengan metode deskriptif-korelasional minimal sebanyak 30 sampel. Adapun sampel pada penelitian ini sebanyak 72 respoden (masyarakat) Kelurahan Layana Indah Kota Palu.

Tehnik penarikan sampel menggunakan snowball sampling, yaitu tehnik penentuan sampel yang awalnya kecil kemudian menjadi besar. Ibarat bola salju yang menggelinding yang lama kelamaan menjadi besar dan teknik ini termasuk dalam non-probabilty sampling yang tidak memberi peluang atau kesempatan bagi anggota populasi untuk dijadikan sampel

Adapun kreteria responden yang akan dijadikan sampel pada penelitian ini adalah:

1. menggunakan sabun deterjen merek Rinso

2. usia minimal 17 tahun

3. bersedia mengisi kuesioner

4. responden sebagai pengambil keputusan pembelian

5. responden adalah masyarakat Kelurahan Layana Indah Kota Palu

\section{HASIL DAN PEMBAHASAN}

\section{Hasil Pengujian Simultan (uji F)}

Pengujian hipotesis pertama dalam penelitian ini menyatakan bahwa kesadaran merek, persepsi kualitas, asosiasi merek dan loyalitas merek secara simultan dapat mempengaruhi keputusan pembelian produk deterjen di Kelurahan Layana Indah Kota Palu. Untuk membuktikan hipotesis pertama, yaitu apakah semua variabel bebas yang dimasukkan dalam model regresi mempunyai pengaruh signifikan secara simultan (bersama-sama) terhadap variabel terikat, digunakan uji $\mathrm{F}$ hasil pengujian secara simultan dapat dilihat pada tabel berikut:

\section{Tabel 1}

\section{Hasil pengujian secara simultan}

\section{ANOVA}

\begin{tabular}{lccccc}
\hline Model & $\begin{array}{c}\text { Sum of } \\
\text { Squares }\end{array}$ & Df & Mean Square & F & Sig. \\
\hline 1 & 7.754 & 4 & 1.938 & 20.809 & $.000^{\mathrm{a}}$ \\
Regression & & & & & \\
\hline \multicolumn{1}{c}{ Residual } & 6.242 & 67 & .093 & & \\
\hline Total & 13.995 & 71 & & & \\
\hline
\end{tabular}

Sumber: Data diolah

Berdasarkan hasi uji ANOVA (analysis of varians diperoleh nilai $\mathrm{F}$ hitung sebesar 20.809, atau lebih besar dari $\mathrm{F}_{\text {tabel }}=3.602$ dan tingkat signifikansi lebih kecil dari taraf ketidakpercayaan $(0,000<$ 0,05). Nilai ini memberikan makna bahwa secara simultan (serempak) variabel kesadaran merek, persepsi kualitas, asosiasi merek dan loyalitas merek secara simultan memengaruhi keputusan pembelian produk deterjen Merek Rinso di Kelurahan Layana Indah Kota Palu. Maka kesimpulannya Ho ditolak, yang artinya hipotesis pertama dalam penelitian ini terbukti sebagai suatu kebenaran empiris (nyata).

Pengaruh semua variabel independen terhadap nilai variabel dependen ditunjukan oleh besarnya koefisieen determinasi yang disesuaikan (adjusted $\mathrm{R}$ square). Pada hasil perhitungan diperoleh 
besarnya koefisien adjusted $\mathrm{R}$ square adalah 0,527 . Artinya pengaruh semua variabel independen terhadap perubahan nilai variabel dependen keputusan pembelian konsumen $(\mathrm{Y})$ adalah $52.7 \%$ dan sisanya $47.3 \%$ dipengaruhi oleh variabel lain di luar model.

\section{Hasil Pengujian Parsial (Uji t)}

Uji t atau uji secara parsial dilakukan dengan membandingkan nilai probabilitas (sig-t) dengan taraf signifikan 0.05. uji parsial pada fungsi estimasi bertujuan untuk membuat kesimpulan mengenai pengaruh masing-masing variabel independen $(\mathrm{X})$ terhadap variabel dependen $(\mathrm{Y})$.

Berdasarkan hasil perhitungan diketahui pengaruh dari variabel kesadarn merek ( X1), persepsi kualitas (X2), asosiasi merek (X3) dan loyalitas merek (X4) masing-masing secara parsial terhadap variabel keputusan pembelian (Y) produk deterjen Rinso di Kelurahan Layana Indah Kota Palu, dengan penjabaran sebagai berikut :

\section{Variabel kesabaran Merek}

Variabel kesadaran merek (X1) diperoleh nilai $t_{\text {hitung }}$ sebesar 4,084 $>t_{\text {tabel }}$ sebesar 1,387, dan tingkat signifikansinya lebih besar dari taraf ketidak percayaan $5 \%(0,000<0,05)$. Pengaruh yang dihasilkan bertanda positif. Ini bermakna bahwa secara parsial variabel kesadaran merek ( $X$ 1) berpengaruh secara positif dan signifikan terhadap keputusan konsumen. Sementara untuk nilai koefisien determinasi parsial $\left(r^{2}\right)$ adalah sebesar 0.961atau sebesar 96.1\%. Hal ini menunjukan bahwa secara parsial variabel kesadaran merek $\left(X_{1}\right)$ mempunyai pengaruh sebesar $96.1 \%$. terhadap keputusan pembelian konsumen. Dengan demikian, melihat hasil tersebut maka hipotesis kedua yang menyatakan bahwa variabel kesadaran merek (X1) mempunyai pengaruh terhadap keputusan konsumen diterima.

\section{Variabel Kesan kualitas}

Variabel kesan kualitas (X2) diperoleh nilai $\mathrm{t}_{\text {hitung }}$ sebesar 2.481 sebesar dan $\mathrm{t}_{\text {tabel }}$ sebesar 1.387, dan tingkat signifikansinya lebih kecil dari taraf ketidakpercayaan 5\% $(0.016<0,05)$. Dengan nilai ini memberikan makna bahwa secara parsial variabel persepsi kualitas $\left(\mathrm{X}_{2}\right)$ memberikan pengaruh secara positif dan signifikan terhadap keputusan pembelian konsumen. Sementara untuk nilai koefisien determinasi parsial $\left(r^{2}\right)$ adalah sebesar 0.721 atau sebesar $72.1 \%$. Hal ini menunjukan bahwa secara parsial variabel persepsi kualitas $\left(\mathrm{X}_{2}\right)$ mempunyai pengaruh besar $72.1 \%$ terhadap keputusan pembelian konsumen. Dengan demikian, melihat hasil tersebut maka hipotesis kedua yang menyatakan bahwa variabel persepsi kualitas $\left(\mathrm{X}_{2}\right)$ mempunyai pengaruh terhadap keputusan konsumen diterima.

\section{Variabel Asosiasi Merek}

Variabel asosiasi merek $\left(\mathrm{X}_{3}\right)$ diperoleh nilai $\mathrm{t}_{\text {hitung }}$ sebesar $3.206>\mathrm{t}_{\text {tabel }}$ sebesar 1.387, dan tingkat signifikansinya lebih kecil dari taraf ketidakpercayaan $5 \%(0.002<0,05)$. Pengaruh yang dihasilkan bertandah positif, maka secara parsial variabel asosiasi merek $\left(\mathrm{X}_{3}\right)$ berpengaruh secara positif dan signifikan terhadap keputusan pembelian konsumen. Sementara untuk nilai koefisien determinasi $\operatorname{parsial}\left(r^{2}\right)$ adalah sebesar 0.752 atau sebesar $75,2 \%$, menunjukkan bahwa sacara parsial variabel asosiasi merak $\left(\mathrm{X}_{3}\right)$ mempunyai pengaruh sebesar $75,2 \%$ terhadap keputusan pembelian konsumen. Dengan demikian, maka hipotesis ketiga yang menyatakan bahwa variabel asosiasi merek $\left(\mathrm{X}_{3}\right)$ berpengaruh terhadap keputusan konsumen diterima.

\section{Variabel Loyalitas Merek}

Variabel loyalitas merek $\left(\mathrm{X}_{4}\right)$ diperoleh nilai $\mathrm{t}_{\text {hitung }}$ sebesar $3.255>\mathrm{t}_{\text {tabel }}$ sebesar 1.387, dan tingkat signifikansinya lebih kecil dari taraf ketidakpercayaan $5 \%(0.002<0,05$. Pengaruh yang dihasilkan bertanda positif, dengan demikian nilai ini memberikan makna bahwa secara parsial variabel loyalitas merek $\left(\mathrm{X}_{4}\right)$ berpengaruh secara positif dan signifikan terhadap keputusan konsumen. Sementara untuk nilai koefisien determinasi parsial $\left(r^{2}\right)$ adalah sebesar 0,913 atau sebesar 91,3\%. Hal ini menunjukan 
bahwa secara parsial variabel loyalitas merek $\left(\mathrm{X}_{4}\right)$ mempunyai pengaruh sebesar $91.3 \%$ terhadap keputusan pembelian konsumen. Dengan demikian maka hipotesis keempat yang menyatakan bahwa variabel loyalitas merek $\left(\mathrm{X}_{4}\right)$ mempunyai pengaruh terhadap keputusan konsumen diterima.

\section{Pengaruh Kesadaran Merek $\left(\mathrm{X}_{1}\right)$ Terhadap Keputusan Pembelian Konsumen}

Hasil penelitian ini menunjukan bahwa masyarakat Kota Palu khususnya pengguna deterjen dalam melakukan pembelian di outlet terdekat cenderung mengutamakan untuk mengingat salah satu iklan mengenai deterjen merek Rinso karena mereka merasa aman dengan suatu yang sudah dikenal. Merek yang sudah dikenal mempunyai kemungkinan bisa diandalkan, kemantapan dalam bisnis, dan kualitas yang bisa dipertanggungjawabkan. Penelitian ini tidak sependapat dengan hasil penelitian yang dilakukan oleh Hardiyanto (2009) dan Asmina (2004) bahwa kesadaran merek berpengaruh secara positif (searah) terhadap keputusan pembelian konsumen.

\section{Pengaruh persepsi kualitas $\left(\mathrm{X}_{2}\right)$ Terhadap Keputusan Pembelian Konsumen.}

Terdapat pengaruh variabel independen persepsi kualitas secara parsial keputusan pembelian konsumen. Dengan demikian hasil penelitian ini mendukung hipotesis kedua. Penelitian ini membuktikan bahwa variabel persepsi kualitas secara posotif mempengaruhi keputusan pembelian konsumen (ditunjukkan dengan koefisien regresi yang positif). Hal ini menunjukkan bahwa masyarakat Kota Palu khususnya pengguna deterjen dalam melakukan pembelian di outlet terdekat lebih mengutamakan kualitas. Sehingga persepsi kualitas akan mempengaruhi langsung keputusan pembelian. Penelitian ini sependapat dengan hasil penelitian yang dilakuakan oleh Hardiyanto (2009) dan Asminah (2004) bahwa persepsi kualitas berpengaruh secara positif (searah) terhadap keputusan pembelian konsumen.

\section{Pengaruh Asosiasi Merek (X3) terhadap keputusan pembelian konsumen}

Hasill penelitian menunjukkan terdapat pengaruh variabel asosiasi merek terhadap keputusan pembelian konsumen. Penelitian ini membuktikan bahwa varibel asosiasi merek secara positif mempengaruhi keputusan pembelian konsumen (ditunjukan dengan koefisien regresi yang positif). Asosiasi merek memiliki hubungan positif dengan keputusan pembelian konsumen, jadi apabila asosiasi merek meningkat, keputusan pembelian konsumen akan bergerak naik. Penelitian sependapat dengan hasil penelitian yang dilakukan oleh Hardiyanto (2009) dan Asminah (2004) bahwa asosiasi merek berpengaruh secara positif (searah) terhadap keputusan pembelian konsumen.

\section{Pengaruh Loyalitas Merek (X4) Terhadap Keputusan Pembelian Konsumen}

Penelitian ini menunjukkan terdapat pengruh variabel loyalitas merek secara parsial terhadap keputusan pembelian konsumen. Dengan demikian hasil penelitian ini mendukung hipotesis kedua. Penelitian ini membuktikan bahwa variabel loyalitas merek secara positif mempengaruhi keputusan pembelian konsumen Hal ini berarti konsumen yang sudah sangat sering melakukan pembelian outlet terdekat, tidak ada lagi merek yang dipertimbangkan untuk dibeli selain merek produk yang sering dibelinya yaitu deterjen Merek Rinso. Penelitian ini sependapat dengan hasil penelitian yang dilakuakan oleh Hardiyanto (2009) dan Asminah (2004) bahwa loyalitas merek berpengaruh secara positif terhadap keputusan pembelian konsumen.

\section{KESIMPULAN DAN SARAN}

\section{Kesimpulan}

Berdasarkan pembahasan yang dilakukan mengenai pengaruh Ekuitas Merek Terhadap Kesimpulan Pembelian Produk Deterjen Merek Rinso Di Kelurahan Layana Indah Kota Palu, maka dapat ditarik kesimpulan sebgai berikut : 
1. Variabel ekuitas merek yang terdiri dari kesadaran merek, kesan kualitas, asosiasi merek dan loyalitas merek berpengaruh signifikan secara simultan terhadap keputusan pembelian produk deterjen merek Rinso di Kelurahan Layana Indah Kota Palu.

2. Variabel kesadaran merek berpengaruh signifikan terhadap keputusan konsumen dalam menggunakan Produk Deterjen Merek Rinso Di Kelurahan Layana Indah Kota Palu.

3. Variabel persepsi kualitas berpengaruh signifikan terhadap keputusan pembelian konsumen dalam menggunakan Prouk Deterjen Merek Rinso Di Kelurahan Layana Indah Kota Palu.

4. Variabel asosiasi merek berpengaruh signifikan terhadap keputusan konsumen dalam menggunakan Produk Deterjen Merek Rinso Di Kelurahan Layana Indah Kota Palu.

5. variabel loyalitas merek berpengaruh signifikan tehadap keputusan konsumen dalam menggunakan Produk Deterjen Merek Rinso Di Kelurahan Layana Indah Kota Palu.

\section{Saran-saran}

Berdasarkan pembahasan dan kesimpulan yang berkaitandengan penelitian ini, maka dapat diberikan saran-saran sebagai berikut:

1. Menambah berbagai macam produk yang berkualitas dengan harga terjangkau dan ditawarkan kepada konsumen dengan desain yang inovatif sehingga konsumen dapat melihat produk yang diingikan dan dibutuhkan. Hal ini sesuai dengan hasil penelitiian yang dinyatakan bahwa asosiasi merek merupaka variabel paling dominan mempengaruhi keputusan konsumen.

2. Mempertahankan kualitas produk dengan harga yang sesuai dengan kualitas serta memberikan diskon bagi konsumen yang melakukan pembelian pada batasan harga tertentu, hal ini memberikan daya tarik bagi konsumen untuk melakukan pembelian Produk Deterjen Merek Rinso Di Kelurahan Layana Indah Kota Palu.

3. Bagi peneliti selanjutnya diharapkan dapat menambah variabel lain untuk repsentatif dalam mempengaruhi keputusan konsumen dalam membeli sebuah produk.

\section{REFERENSI}

Aaker, A. David. (2007). Manajemen Ekuitas Merek (memanfaatkan nilai dari suatu merek), alih bahasa Ari Sananda, cetakan pertama, Mitrautama, Jakarta

Assauri, Sofjan. (2010). Manajemen Pemasaran, Cetakan ke-10, PT. Rajagrafindo Persada, Jakarta.

Darmadi, Durianto. (2001). Brand Equity Ten: Strategi Memimpin Pasar. PT. Gramedia Pustaka Utama, Jakarta.

Ghozali. (2001). Uji Asumsi Klasik. Bandung.

Hasan. (2003). Analisis Regresi LinearBberganda. Bandung.

Kusuma, Hastuti Yenny. (2012). Menganalisis Keputusan Pembelian Sepeda Motor Merek Yamaha di Kota Sengkawang. Jurnal Program Studi Magister Manajemen Fakultas Ekonomi Universitas Tanjungpura.

Kelurahan Layana Indah. (2014). Profil Layana Indah, Palu.

Kotler, Philip \& Keller, Kevin. (2009). Manajemen Pemasaran, Edisi Ketigabelas, Jilid 1, Penerbit Erlangga, Jakarta.

Kuncoro, Mudrajat (2009). Metode Riset Untuk Bisnis Ekonomi, Edisi 3. AMP YKPN, Jakarta.

Nugroho Setiadi J. (2003). Perilaku Konsumen: Prenada Media, Jakarta.

Aryo, Pramono Agil. (2011). Analisis Pengaruh Elemen-elemen ekuitas merek terhadap keputusan pembelian pada notebook Toshiba di Semarang, Jurnal Fakultas Ekonomi Universitas Diponegoro. 
Rangkuti, Fredy (2009). Pengertian Ekuitas Merek, PT. Gramedia Pustaka Utama, Jakarta.

Setiawati, Ni Wayan. (2013). Pengaruh Ekuitas Merek terhadap Keputusan Pembelian Produk Shophie Martin" di Kota Palu. Skripsi Jurusan Manajemen, Fakultas Ekonomi Universitas Tadulako, Palu.

Sugiyono. (2008). Metode Penelitian Bisnis, Cetakan kedua belas, Penerbit Alfabeta,

Bandung.

Sulianto. (2006). Metode Riset Bisnis, penerbit Andi, Yogyakarta.

Supratno. (2002). Metode Penelitian. Erlangga, Jakarta.

Tjiptono, Fandy. (2005). Ekuitas Merek. Andi Offset. Yogyakarta.

Suliyanto. (2006). Pengantar Teknologi, Edisi Pertama. Jakarta : Ghalia Indonesia, Bogor.

Umar. (2000). Riset Pemasaran dan Perilaku Konsumen, PT. Gramedia Pustaka Utama, Jakarta.

Umar, Husein. (2003). Riset Pemasaran Dan Perilaku Konsumen, PT. Gramedia Pustaka Utama, Jakarta.

WirastomoWahyu Arti. (2012). Analisis pengaruh ekuitas merek terhadap keputusan pembelian sepeda motor (studi pada pelanggan PT Yamaha Agung Motor Semarang). Jurnal Fakultas Ekonomika dan Bisnis Universitas Diponegoro.

Wicaksono, Darmawan. (2013). Pengaruh elemen ekuitas merek terhadap perilaku konsumen dalam melakukan keputusan pembelian Iphone (studi pada pengguna Iphone di Kota Semarang), Jurnal Fakultas Ekonomika dan Bisnis Universitas Diponegoro. 